University of Nebraska - Lincoln

DigitalCommons@University of Nebraska - Lincoln

\title{
Hepatitis Associated with a Sarcocystis canis-like Protozoan in a Hawaiian Monk Seal (Monachus schauinslandi)
}

D. Yantis

Armed Forces Institute of Pathology

R. Moeller

Armed Forces Institute of Pathology

R. Braun

Kaneohe Bay Drive

C. H. Gardiner

Armed Forces Institute of Pathology

A. Aguirre

University of Hawaii

See next page for additional authors

Follow this and additional works at: https://digitalcommons.unl.edu/usdaarsfacpub

Part of the Agricultural Science Commons

Yantis, D.; Moeller, R.; Braun, R.; Gardiner, C. H.; Aguirre, A.; and Dubey, J. P., "Hepatitis Associated with a Sarcocystis canis-like Protozoan in a Hawaiian Monk Seal (Monachus schauinslandi)" (2003).

Publications from USDA-ARS / UNL Faculty. 413.

https://digitalcommons.unl.edu/usdaarsfacpub/413

This Article is brought to you for free and open access by the U.S. Department of Agriculture: Agricultural Research Service, Lincoln, Nebraska at DigitalCommons@University of Nebraska - Lincoln. It has been accepted for inclusion in Publications from USDA-ARS / UNL Faculty by an authorized administrator of DigitalCommons@University of Nebraska - Lincoln. 
Authors

D. Yantis, R. Moeller, R. Braun, C. H. Gardiner, A. Aguirre, and J. P. Dubey 


\section{Hepatitis Associated with a Sarcocystis canis-like Protozoan in a Hawaiian Monk Seal (Monachus schauinslandi)}

D. Yantis, R. Moeller, R. Braun*, C. H. Gardiner, A. Aguirre†, and J. P. Dubey $§$, Armed Forces Institute of Pathology, Washington, D.C. 20306-6000; * Kaneohe Bay Drive, Kaneohe Bay, Hawaii 96744; † Joint Institute for Marine and Atmospheric Research, University of Hawaii, Honolulu, Hawaii 96822-2396; ‡ Animal Parasitic Diseases Laboratory, Animal and Natural Resources Institute, Beltsville Agricultural Research Center, United States Department of Agriculture, Beltsville, Maryland 20705-2350; § To whom correspondence should be addressed. e-mail: jdubey@anri.barc.usda.gov

ABSTRACT: A Hawaiian monk seal (Monachus schauinslandi) died in captivity at the National Marine Fisheries Service, Kewalo Basin Facility in Honolulu, Hawaii. The animal was icteric, and the liver was friable. Microscopic lesions were detected in the colon and liver. Colonic lesions included multifocal, necrohemorrhagic colitis associated with gram-negative bacilli. The liver lesions included random hepatic necrosis and cholestasis. Asexual stages of a Sarcocystis canis-like apicomplexan were detected in hepatocytes. The parasite divided by endopolygeny. Merozoites occasionally formed rosettes around a central residual body. Ultrastructurally, merozoites lacked rhoptries. This is the first report of $S$. canis infection in M. schauinslandi, which is an endangered pinniped in U.S. waters.

Sarcocystis species generally have a 2-host predator-prey life cycle, with an asexual cycle in herbivores and a sexual cycle in carnivores (Dubey et al., 1989). Sarcocystis species are generally specific for their intermediate host. A new group of Sarcocystis parasites, e.g., S. neurona and $S$. canis, were discovered in the past decade with unusual host range and life cycles. Sarcocystis neurona causes neurologic disorders in horses and a variety of other animals, including marine mammals. They are considered to be aberrant hosts because only schizonts are found in these hosts and are confined to the central nervous system (Dubey et al., 2001). Opossums are the definitive hosts shedding sporocysts of $S$. neurona; cats, skunks, sea otters, and armadillos can act as intermediate hosts with sarcocysts in their muscles.

Sarcocystis canis is related to S. neurona, but its life cycle is unknown (Dubey and Speer, 1991). Only the schizont stage is known, and it is confined mostly to the liver. It produces fatal hepatitis in dogs, chinchillas, bears, horses, sea lions, and dolphins (Dubey and Speer, 1991; Mense et al., 1992; Rakich et al., 1992; Zeman et al., 1993; Garner et al., 1997; Davis et al., 1999; Resendes et al., 2002; Berrocal and Lopez, 2003).

The Hawaiian monk seal (Monachus schauinslandi) is an endangered pinniped in U.S. waters, and its population has been steadily decreasing since 1950. We report fatal $S$. canis infection in this host for the first time.

During 1995, 12 weaned, underweight Hawaiian monk seal pups were taken from French Frigate Shoals, Northwestern Hawaiian Islands, to facilities on the Hawaiian island of Oahu for rehabilitation and subsequent release. Release plans were suspended when a majority of the seal pups developed ocular disease, leading to corneal opacities and blindness. This had not been encountered previously in rehabilitating seal pups. The 21-mo-old female seal in this study was retained in captivity for investigation of the ocular disease. It died in 1997, while in quarantine for treatment of an acute gastrointestinal illness, at the National Marine Fisheries Service, Kewalo Basin Facility, Honolulu, Hawaii. A necropsy was performed by National Marine Fisheries Service personnel within $3 \mathrm{hr}$ of death. Tissue specimens were fixed in $10 \%$ formalin and submitted to the Armed Forces Institute of Pathology, Washington, D.C., for histopathologic examination. Tissues were processed routinely, sectioned, stained with hematoxylin and eosin (HE), and examined microscopically. Portions of liver were embedded in methacrylate, sectioned at 3- to 4- $\mu \mathrm{m}$ thickness, and stained with HE. Formalin-fixed portions of liver were processed for transmission electron microscopy. Deparaffinized sections were stained with polyclonal sera of Toxoplasma gondii, Neospora caninum, S. cruzi, and S. neurona as described elsewhere (Lindsay and Dubey, 1989; Dubey et al., 1991; Dubey and Hamir, 2000).
The seal was in excellent body condition with normal dentition and no signs of trauma or injury. Gross lesions included bilateral, central corneal opacities and cataracts; generalized icterus; and petechial and ecchymotic hemorrhage in the meninges, alimentary tract, multiple lymph nodes, kidney, urinary bladder, pancreas, and liver. The liver was friable. Marked microscopic lesions were present in the colon and liver. Colonic lesions included multifocal necrosis and loss of mucosa associated with moderate numbers of viable and degenerate neutrophils, fewer erythrocyte and debris-macrophages, hemorrhage, and moderate numbers of gram-negative bacilli. The liver contained random foci of hepatocellular necrosis (Fig. 1), characterized by eosinophilic cellular and karyorrhectic debris interspersed with erythrocyte- and debris-laden macrophages and small numbers of lymphocytes and plasma cells, all surrounded by hemorrhage. Multifocally, there was globular, yellowbrown pigmented material in hepatocytes and distending bile canaliculi, interpreted as cholestasis. Diffusely, hepatocytes contained single to multiple, discrete, round, intracytoplasmic vacuoles interpreted as lipid accumulation.

Numerous protozoa were found in the cytoplasm of hepatocytes surrounding the areas of necrosis (Figs. 1,2). Only asexual stages were

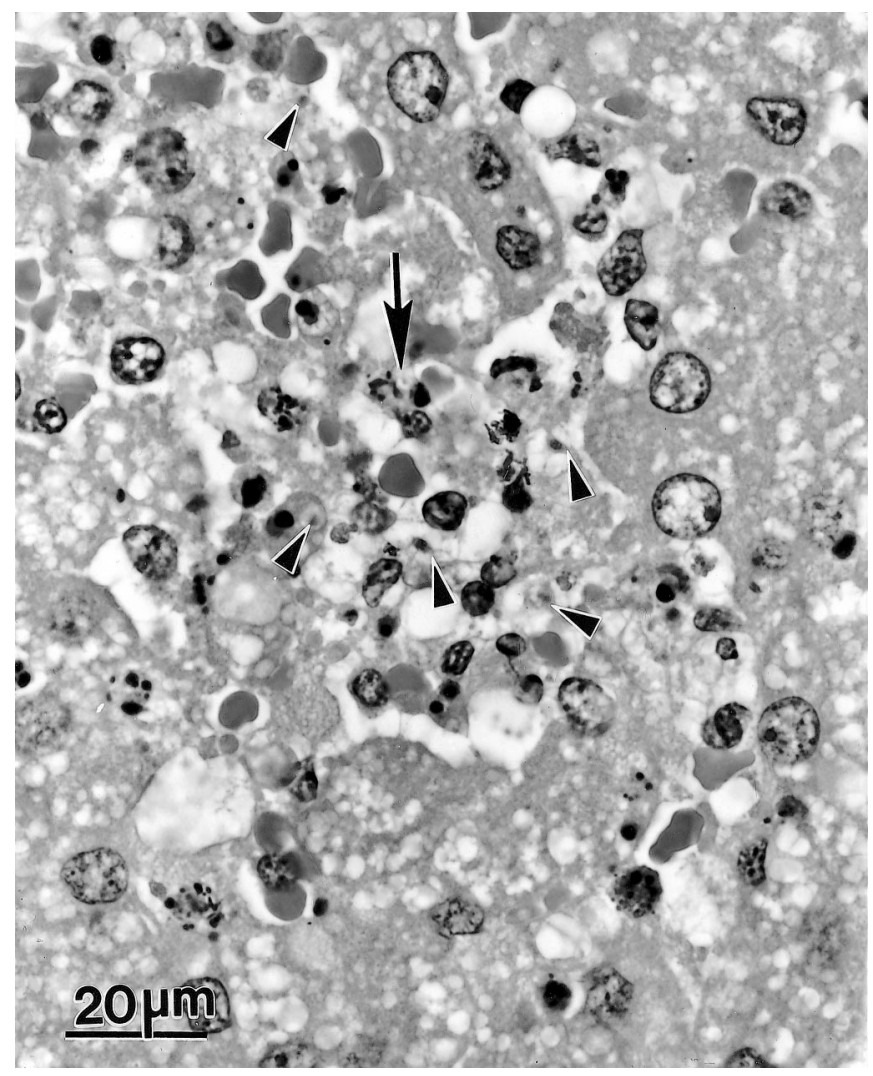

FIGURE 1. Hepatic degeneration and necrosis (arrow) and individual merozoites (arrowheads) in liver of the Hawaiian monk seal. HE. 

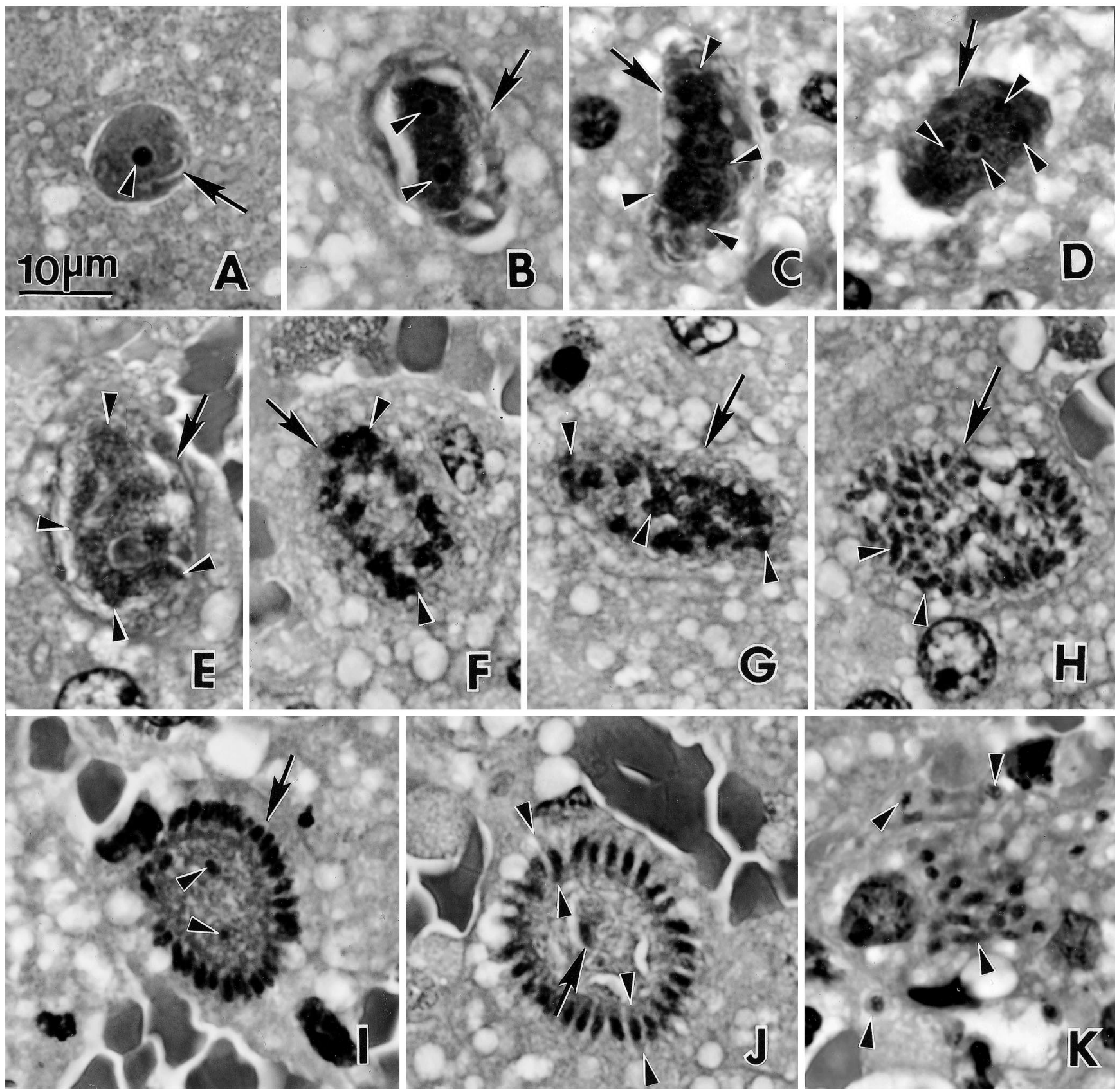

FiguRE 2. Developmental stages of a Sarcocystis canis-like merozoite in hepatocytes of the monk seal. HE. Bar applies to all parts. (A) Uninucleate organism with a prominent endosome (arrowhead) in the nucleus and clefts (arrow) in the cytoplasm. (B) Schizont (arrow) with bilobed nucleus, each with an endosome (arrowhead). (C) Schizont (arrow) with a trilobed nucleus, each with an endosome. (D) Schizont (arrow) with a nucleus containing several endosomes (arrowheads). (E) Schizont (arrow) with a lobulated nucleus (arrowheads). (F) Schizont (arrow) with nuclear lobes (arrowhead) arranged peripherally. (G) Schizont (arrow) with nuclear lobes arranged haphazardly. (H) Schizont (arrow) with merozoites (arrowheads) distributed throughout the cytoplasm. (I) Schizont (arrow) with merozoites arranged at the periphery. The central mass contains dark bodies (arrowheads) presumed to be merozoite nuclei. (J) Mature schizont with a residual mass (arrow) and merozoites (opposing arrowheads) at the periphery. (K) Individual scattered merozoites (arrowheads).

seen. Both immature and mature schizonts were present. The earliest schizonts were up to $9 \mu \mathrm{m}$ wide and contained a large nucleus with a prominent nucleolus (Fig. 2A). The parasite was undergoing endopolygeny, a process in which the nucleus becomes enlarged and multilobulated before dividing into numerous merozoites (Fig. 2B-G). Mature schizonts varied in shape and size, occupied most of the hepatocyte cytoplasm, and displaced the cell nucleus peripherally. Schizonts were up to $25 \mu \mathrm{m}$ in diameter and contained a variable number of merozoites; 32 merozoites are present in 1 plane of section in Fig. 1J. Merozoites were arranged haphazardly or budded peripherally, occasionally around a residual body (Fig. 2I, J). Merozoites varied in length and shape. The longest merozoites were $4 \mu \mathrm{m}$ long in section (Fig. 1F). Individual merozoites were rarely seen within hepatocytes or free in the foci of necrosis (Fig. 1).

Ultrastructurally, schizonts appeared to lie directly in the cytoplasm of hepatocytes, with no visible parasitophorous membrane. Merozoites contained numerous micronemes, a conoid, and a centrally placed nucleus but no rhoptries (Fig. 3). 


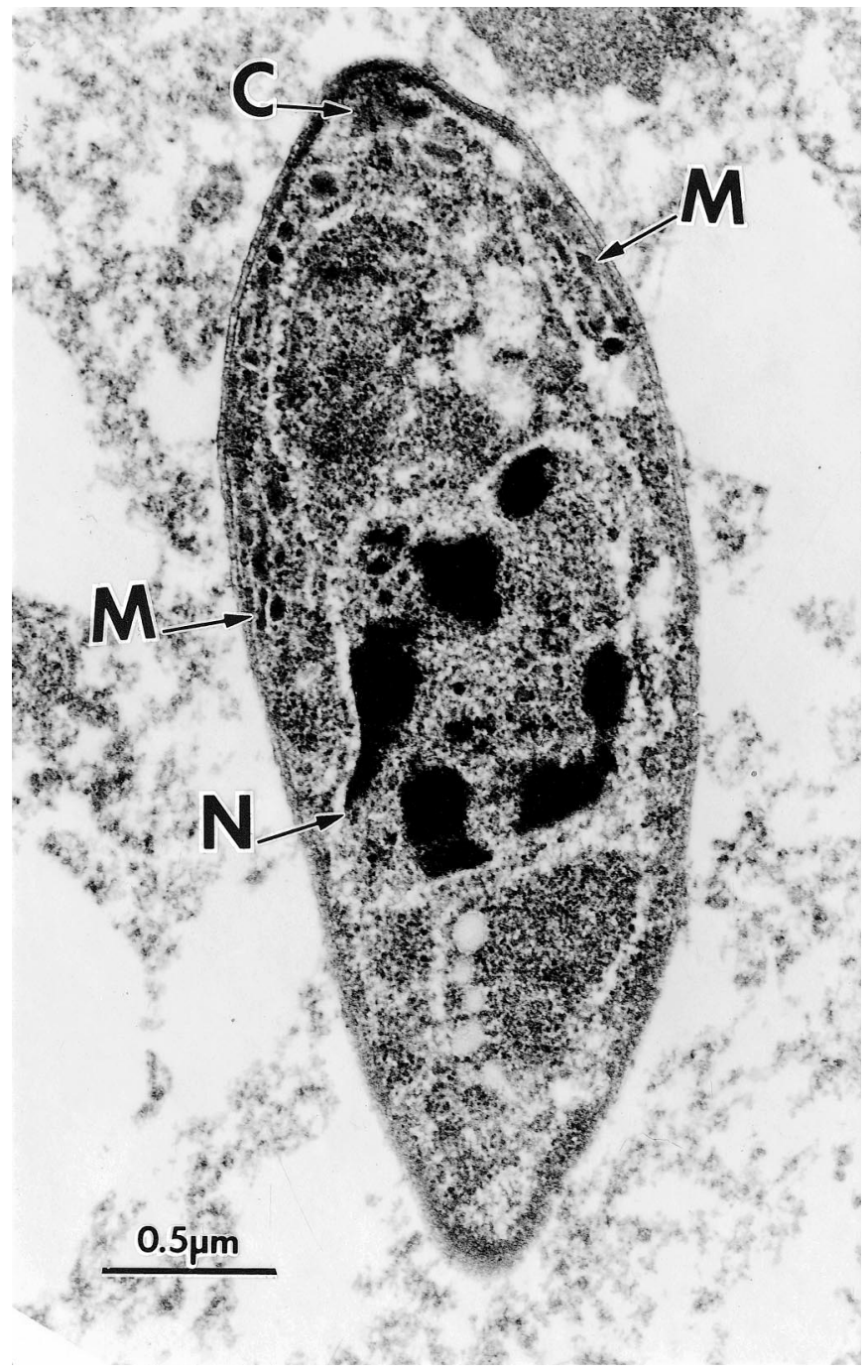

FIGURE 3. Transmission electron micrograph of a longitudinally sectioned Sarcocystis canis-like merozoite. Note the conoid (C) and micronemes $(\mathrm{M})$ anterior to the nucleus $(\mathrm{N})$ and the absence of rhoptries.

The protozoa reacted positively to $S$. cruzi polyclonal serum, which is genus specific but not species specific (Dubey et al., 1991), and did not react with $T$. gondii, $N$. caninum, and $S$. neurona polyclonal sera. The cause of death was considered to be the combined effects of the necrotizing colitis associated with unidentified gram-negative bacilli and the necrotizing hepatitis associated with $S$. canis.

The parasite was considered to be $S$. canis based on the structure The parasite in this case was not $T$. gondii or $N$. caninum because it divided by endopolygeny, a specialized form of schizogony in which the nucleus divides into several interconnected lobes. Toxoplasma gon- dii and $N$. caninum divide by endodyogeny, or division into 2 distinct lobes. Additionally, the parasite did not react to T. gondii and N. caninum antibodies. It was also distinct from $S$. neurona because of the parasite location in the liver and the nonreactivity to $S$. neurona antibody. Sarcocystis neurona schizonts are found in the central nervous system (Dubey et al., 2001). The source of $S$. canis infection in any host is unknown, but infections have been reported from the United States, Spain, and Costa Rica, suggesting that the definitive host for this apicomplexan is not confined to North America (Dubey and Speer, 1991; Resendes et al., 2002; Berrocal and Lopez, 2003).

All materials pertaining to this case are deposited in the records of Armed Forces Institute of Pathology, Washington, D.C. (case no. AFIP 2584162).

\section{LITERATURE CITED}

Berrocal, A., AND A. LoPez. 2003. Pulmonary sarcocystosis in a puppy with canine distemper in Costa Rica. Journal of Veterinary Diagnostic Investigation 15: 292-294.

Davis, C. R., B. C. Barr, J. R. Pascoe, H. J. Olander, and J. P. Dubey. 1999. Hepatic sarcocystosis in a horse. Journal of Parasitology 85: 965-968.

Dubey, J. P., S. W. Davis, C. A. Speer, D. D. Bowman, A. De Lahunta, D. E. Granstrom, M. J. Topper, A. N. Hamir, J. F. Cummings, AND M. M. SUTER. 1991. Sarcocystis neurona n. sp. (Protozoa: Apicomplexa), the etiologic agent of equine protozoal myeloencephalitis. Journal of Parasitology 77: 212-218.

- AND A. N. HAMIR. 2000. Immunohistochemical confirmation of Sarcocystis neurona infections in raccoons, mink, cat, skunk and pony. Journal of Parasitology 86: 1150-1152.

, D. S. Lindsay, W. J. A. Saville, S. M. Reed, D. E. GranSTROM, AND C. A. SpeER. 2001. A review of Sarcocystis neurona and equine protozoal encephalitis (EPM). Veterinary Parasitology 95: 89-131.

- AND C. A. SPEER. 1991. Sarcocystis canis n. sp. (Apicomplexa: Sarcocystidae), the etiologic agent of generalized coccidiosis in dogs. Journal of Parasitology 77: 522-527.

_, C. A. Speer, AND R. FAYer. 1989. Sarcocystosis of animals and man. CRC Press, Boca Raton, Florida, 215 p.

Garner, M. M., B. C. Barr, A. E. Packham, A. E. Marsh, K. A Burek-Huntington, R. K. Wilson, And J. P. Dubey. 1997. Fatal hepatic sarcocystosis in two polar bears (Ursus maritimus). Journal of Parasitology 83: 523-526.

LiNDSAY, D. S., AND J. P. DUBEY. 1989. Immunohistochemical diagnosis of Neospora caninum in tissue sections. American Journal of Veterinary Research 50: 1981-1983.

Mense, M. G., J. P. Dubey, And B. L. Homer. 1992. Acute hepatic necrosis associated with a Sarcocystis-like protozoa in a sea lion (Zalophus californianus). Journal of Veterinary Diagnostic Investigation 4: 486-490.

Rakich, P. M., J. P. Dubey, And J. K. Contarino. 1992. Acute hepatic sarcocystosis in a chinchilla. Journal of Veterinary Diagnostic Investigation 4: 484-486.

Resendes, A. R., C. Juan-Sallés, S. Almeria, N. Majó, M. Domingo, AND J. P. Dubey. 2002. Hepatic sarcocystosis in a striped dolphin (Stenella coeruleoalba) from the Spanish Mediterranean coast. Journal of Parasitology 88: 206-209.

Zeman, D. H., J. P. Dubey, AND D. Robison. 1993. Fatal hepatic sarcocystosis in an American black bear. Journal of Veterinary Diagnostic Investigation 5: 480-483. 